\title{
Phase Change Material Selection for Thermal Energy Storage at High Temperature Range between $210^{\circ} \mathrm{C}$ and $270{ }^{\circ} \mathrm{C}$
}

\author{
José Miguel Maldonado ${ }^{1}$, Margalida Fullana-Puig ${ }^{1,2}$, Marc Martín ${ }^{1}$ (D), Aran Solé ${ }^{3}$, \\ Ángel G. Fernández ${ }^{4}$, Alvaro de Gracia ${ }^{1,2}$ and Luisa F. Cabeza ${ }^{1, * \text { (ID) }}$ \\ 1 GREiA Research Group, INSPIRES Research Centre, Universitat de Lleida, Pere de Cabrera s/n, \\ 25001 Lleida, Spain; jmmaldonado@diei.udl.cat (J.M.M.); mfullana@diei.udl.cat (M.F.-P.); \\ marc.martin@udl.cat (M.M.); alvaro.degracia@udl.cat (A.d.G.) \\ 2 CIRIAF-Interuniversity Research Centre on Pollution and Environment Mauro Felli, Via G. Duranti 63, \\ 06125 Perugia, Italy \\ 3 Department of Mechanical Engineering and Construction, Universitat Jaume I, Av. Vicent Sos Baynat, s/n, \\ 12071 Castellón de la Plana, Spain; sole@uji.es \\ 4 Energy Development Center, University of Antofagasta, Av. Universidad de Antofagasta, 02800 Antofagasta, \\ Chile; angel.fernandez@uantof.cl \\ * Correspondence: lcabeza@diei.udl.cat
}

Received: 23 February 2018; Accepted: 27 March 2018; Published: 8 April 2018

\begin{abstract}
The improvement of thermal energy storage systems implemented in solar technologies increases not only their performance but also their dispatchability and competitiveness in the energy market. Latent heat thermal energy storage systems are one of those storing methods. Therefore, the need of finding the best materials for each application becomes an appealing research subject. The main goal of this paper is to find suitable and economically viable materials able to work as phase change material (PCM) within the temperature range of $210-270{ }^{\circ} \mathrm{C}$ and endure daily loading and unloading processes in a system with Fresnel collector and an organic Rankine cycle (ORC). Twenty-six materials have been tested and characterized in terms of their thermophysical conditions, thermal and cycling stability, and health hazard. Two materials out of the 26 candidates achieved the last stage of the selection process. However, one of the two finalists would require an inert working atmosphere, which would highly increase the cost for the real scale application. This leads to a unique suitable material, solar salt (40 wt \% $\mathrm{KNO}_{3} / 60 \mathrm{wt} \% \mathrm{NaNO}_{3}$ ).
\end{abstract}

Keywords: thermal energy storage (TES); Fresnel collector; thermal stability; cycling stability; thermophysical properties; health hazard; myo-inositol; solar salt; infrared spectroscopy (IR); differential scanning calorimetry (DSC)

\section{Introduction}

Tackling greenhouse effect emissions by decarbonising energy production is one of the European Commission's main concerns. Therefore, solar energy has been highly promoted to globally reduce the carbon footprint. Among other solar energy technologies, concentrated solar thermal energy could cover up to $7 \%$ of world energy demand by 2030 and $25 \%$ by 2050 if considering advanced development in its efficiency [1].

To increase solar thermal power plants' competitiveness against fossil fuels power plants, their dispatchability needs to be enhanced so that they can dispatch power on grid demand or according to market needs. Thermal energy storage (TES) systems can accomplish that requirement, allowing solar thermal plants to generate energy consistently at times when sunlight is not available, 
which makes the power plant more cost effective. Thermal energy storage also allows greater use of the power-block components and increase grid flexibility.

The improvement of thermal energy storage systems is continuously targeted by researchers, and this is studied in any of the three technologies of TES: sensible heat, latent heat, or sorption and chemical reactions (also known as thermochemical energy storage). Among TES technologies, latent storage using phase change materials (PCM) offers an effective solution since it has high energy storage density and the melting and solidification processes undertaken by PCM are almost isothermal [2].

Research and development efforts within the solar energy industry are focused on lowering the high operation and maintenance cost of solar plants. The choice of PCM has a strong influence on such costs; not only the material itself but also indirect costs such as its container and the safety measurements that the material requires. Therefore, it is crucial to perform an exhaustive phase change material selection process considering materials cost, availability, and their facilities requirements.

Differential scanning calorimeter (DSC) and thermal gravimetric analysis (TGA) are widely used techniques to characterize PCMs [3-7]. Haillot et al. [3] characterized 11 materials using DSC and TGA coupled with a quadrupole mass spectrometer (QMS). The study checked solid-solid transition materials, sugar alcohols, polymeric hydrocarbons, and aromatic hydrocarbons among other materials that can be used in applications with interest in the $120-150{ }^{\circ} \mathrm{C}$ temperature range. The analyses were performed before and after five thermal cycles, concluding that only a few organic materials showed potential for thermal storing purposes and further investigations are needed regarding long-term stability. Their study pointed out the relevance of the measurement conditions over the results.

Del Barrio et al. [4] evaluated the key thermal and physical properties of five sugar alcohols and three eutectic blends; their aim was to compare them with the PCM currently used within $70{ }^{\circ} \mathrm{C}$ and $180^{\circ} \mathrm{C}$. The study concluded that sugar alcohols seem to be suitable materials for latent heat storage. However, several issues, such as sugar alcohol thermal endurance and stability, must be faced by further research.

Bayón et al. [5] performed DSC and TGA analysis, coupled with polarized light microscopy and rheological measurements, on liquid crystals to check their feasibility as latent heat storage material. They concluded that, despite the promising results shown by those materials, their long-term thermal stability should be further studied.

Miro et al. [6] and Gasia et al. [7] also included health hazard analysis to take into account the PCM effect on living beings and their impact on the facilities maintenance and design. Miro et al. [6] added, to the latter analysis, thermal stability and thermal cycling tests to check the aging of the PCM. Five different materials were tested within a $150^{\circ} \mathrm{C}$ and $200{ }^{\circ} \mathrm{C}$ temperature range, concluding that the suitable materials at that temperature range are benzanilide and D-mannitol; the authors also considered hydroquinone when used in a closed system. Gasia et al. [7] characterized 16 materials; their phase change temperature comprised from 120 to $200^{\circ} \mathrm{C}$ and cycling stability up to 100 cycles. They concluded that adipic acid and high-density polyethylene are fit candidates as PCMs for the studied temperature range.

The overall objective of this study is to find suitable phase change materials to store thermal energy in a temperature range from 210 to $270{ }^{\circ} \mathrm{C}$, which fits the real application requirements. As sundown takes place, the energy source is cut out. To keep-up with production, the TES takes over as the energy supplier. Therefore, the PCM has to endure daily phase changes. The first stage of this research is to perform a materials screening, considering both organic and inorganic materials in order to select suitable candidates according to literature. Afterward, their health hazard was evaluated, and their thermophysical properties where characterized by means of DSC. This process led to the final candidates that were deeply characterized with thermal stability and cycling stability tests under real operation conditions. Finally, results were discussed according to the defined requirements. 


\section{Materials Screening}

In order to select the appropriate material a preliminary screening was done. Considered materials were divided into inorganic and organic groups in the following subsections.

\subsection{Inorganic Materials}

At the temperature range of a solar plant output application, different inorganic materials can be considered for use as PCMs. Common examples of inorganic materials are several technical salts and binary eutectic mixtures of such salts shown in Table 1.

Table 1. Inorganic salt phase change material (PCM) candidates with phase change temperature between $210{ }^{\circ} \mathrm{C}$ and $270{ }^{\circ} \mathrm{C}$.

\begin{tabular}{|c|c|c|c|c|}
\hline Inorganic Salt & Price $(€ /$ kg) & Melting Temperature $\left({ }^{\circ} \mathrm{C}\right)$ & Melting Enthalpy (J/g) & Reference \\
\hline 80 wt $\% \mathrm{NaOH} / 20$ wt $\% \mathrm{LiOH}$ & 52.3 & 215 & 280 & {$[8,9]$} \\
\hline 40 wt $\% \mathrm{KNO}_{3} / 60$ wt $\% \mathrm{NaNO}_{3}$ & 33 & 222 & 100 & [10-12] \\
\hline $\mathrm{NaNO}_{3} / \mathrm{NaNO}_{2}$ * & 39.3 & $226-233$ & n.a. & [13] \\
\hline 45 wt $\% \mathrm{Ca}\left(\mathrm{NO}_{3}\right)_{2} / 55$ wt $\% \mathrm{NaNO}_{3}$ & 40.3 & 230 & $\sim 110$ & [10] \\
\hline 61 wt $\% \mathrm{NaOH} / 39$ wt $\% \mathrm{NaNO}_{2}$ & 32.9 & $232-265$ & $250-300$ & [14] \\
\hline 87 wt $\% \mathrm{NaNO}_{2} / 13$ wt $\% \mathrm{NaOH}^{*}$ & 33.2 & $230-232$ & $206-252$ & [14] \\
\hline $\mathrm{Ca}\left(\mathrm{NO}_{3}\right)_{2} / \mathrm{LiNO}_{3}$ & 90.6 & 235 & n.a. & [15] \\
\hline $\mathrm{LiNO}_{3}$ & 147 & 252 & 380 & [16] \\
\hline $\mathrm{NaNO}_{2}$ & 33.25 & 270 & 200 & {$[17]$} \\
\hline
\end{tabular}

From the economic point-of-view, several materials are expensive due to the presence of Li ( $>150 € / \mathrm{kg}$ for pure lithium). In contrast with inorganic salts, pure metals and alloys have high thermal conductivity and small volume change during phase change process. A TES system based on these materials could provide fast thermal response and high operational power according to recently performed studies $[18,19]$. Nevertheless, their energy density, fast thermal response, and high operational power do not pay off the high cost of the material. Classified by phase change temperature, metal PCMs can generally be divided into three categories: low temperature $\left(0-30{ }^{\circ} \mathrm{C}\right)$, middle temperature $\left(40-200{ }^{\circ} \mathrm{C}\right)$, and high temperature $\left(>200^{\circ} \mathrm{C}\right)$ [20]. In this case, high-temperature phase change material is required in the $210-270{ }^{\circ} \mathrm{C}$ temperature range (Table 2). However, as stated by Fernández et al. [21], metal PCM present several issues to be considered: vapor pressure, subcooling, corrosion or other undesired reactions, segregation, and changes in composition and microstructure due to thermal cycling. Therefore, metal PCMs are excluded from this study since further research is needed before these materials can be used as PCMs in thermal energy storage systems at industrial scale.

Table 2. Metal PCM candidates with phase change temperature between $210{ }^{\circ} \mathrm{C}$ and $270{ }^{\circ} \mathrm{C}$.

\begin{tabular}{cccc}
\hline Metal & Price $(\boldsymbol{\epsilon} / \mathbf{k g})$ & Melting Temperature $\left({ }^{\circ} \mathbf{C}\right)$ & Reference \\
\hline Lead-Antimony alloys & $2-3$ & $251-254$ & {$[22]$} \\
Lead, babbitt metall alloy $(\mathrm{Cu}, \mathrm{Pb}, \mathrm{Sb}$, etc. $)$ & $2.5-4$ & $237-272$ & {$[22]$} \\
Lead-Tin alloys & $5-6$ & $183-277$ & {$[22]$} \\
Lead-Magnesium eutectic alloy & n.a. & 249 & {$[23]$} \\
Tin-Lead alloys & $13-14$ & $181-296$ & {$[22]$} \\
Tin, babbitt metall alloys & $16-19$ & $241-354$ & {$[22]$} \\
Tin-Antimony alloys & $7-7.5$ & $236-256$ & {$[22]$} \\
Tin (pure) & $7-7.5$ & $227-232$ & {$[22]$} \\
Tin-silver alloys & $35-40$ & $221-222$ & {$[22]$} \\
Selenium (pure) & $37-43$ & 221 & {$[22]$} \\
\hline
\end{tabular}




\subsection{Organic Materials}

Organic PCMs offer advantages compared with inorganic PCMs, such as practically null corrosion and low or no subcooling. In contrast, they generally show lower thermal conductivity and phase change enthalpies as well as higher flammability. Nevertheless, three organic materials have been found with promising properties in the chosen temperature range. Table 3 shows the two sugar alcohols and the polymer, respectively.

Table 3. Organic PCM candidates with phase change temperature between $210{ }^{\circ} \mathrm{C}$ and $270{ }^{\circ} \mathrm{C}$.

\begin{tabular}{cccccc}
\hline $\begin{array}{c}\text { Organic } \\
\text { Material }\end{array}$ & $\begin{array}{c}\text { Molecular } \\
\text { Formula }\end{array}$ & Price $(\boldsymbol{\epsilon} / \mathbf{k g})$ & $\begin{array}{c}\text { Melting Temperature } \\
\left({ }^{\circ} \mathbf{C}\right)\end{array}$ & $\begin{array}{c}\text { Melting } \\
\text { Enthalpy (j/g) }\end{array}$ & Reference \\
\hline Pentaerythritol & $\mathrm{C}_{5} \mathrm{H}_{12} \mathrm{O}_{4}$ & $9.7-13^{*}$ & $258-260$ & n.a. & {$[24]$} \\
Myo-Inositol & $\mathrm{C}_{6} \mathrm{H}_{12} \mathrm{O}_{6}$ & $8-10^{*}$ & 220 & 190 & {$[25]$} \\
PBT & $\left(\mathrm{C}_{12} \mathrm{H}_{12} \mathrm{O}_{4}\right)_{n}$ & $2.14-2.36$ & $220-267$ & n.a. & {$[20]$} \\
PCTFE & $\left(\mathrm{CF}_{2} \mathrm{CClF}\right)_{n}$ & $87.7-105$ & $206-226$ & n.a. & {$[20]$} \\
\hline
\end{tabular}

Sugar alcohols are relatively new materials in the TES field [25]. They show potential to be implemented as PCM since they have high phase change enthalpy, low cost, and are non-toxic [26]. Pentaerythritol also has a solid-solid phase change transition at $182-183{ }^{\circ} \mathrm{C}$ largely studied for use as a PCM. For example, Hu et al. [27] included it in a composite with nano-AlN confirming improvements in the crystallization process. A study comparing charging/discharging process with different fin volume ratios was carried out by Khonjera et al. [28]. A novel point-of-view is given in this cited paper since there is a lack of pentaerithritol studies as a PCM concerning its solid-liquid phase change transition. Myo-inositol thermal cycling stability has been broadly studied by Solé et al. [25]. Although some chemical changes were identified by FT-IR analysis, acceptable thermal performance was observed after 50 cycles between $150{ }^{\circ} \mathrm{C}$ and $260^{\circ} \mathrm{C}$. However, new crystalline structures were observed when thermal cycling range was extended to $50-260^{\circ} \mathrm{C}$.

Thermoplastic polymers present potential to be used as PCM since they have semi-crystalline structure and, therefore, noteworthy energy related to their phase change. Based on this, high-density polyethylene (HDPE) has been extensively studied and several times proposed as PCM for $100-150{ }^{\circ} \mathrm{C}$ temperature range applications [3,7]. Nevertheless, no polymeric PCMs have been found in the literature for the temperature range $\left(210-270{ }^{\circ} \mathrm{C}\right)$ of interest in this paper. Thus, two new polymeric materials are considered for their application as phase change materials since they have semi-crystalline structure and suitable phase change temperature. Polybutylene terephthalate (PBT) is an engineering polymer typically used in electric and electronics industries; it presents low price and, due to its regular radical distribution in the aromatic rings, it ensures a high degree of crystallinity and has low shrinkage during solid-liquid phase change transition. Polychlorotrifluoroethylene (PCTFE) finds its applications due to its non-flammable properties and high chemical stability.

\section{Materials and Methodology}

\subsection{Materials}

Nine phase change materials with melting temperatures between $210{ }^{\circ} \mathrm{C}$ and $270{ }^{\circ} \mathrm{C}$ were selected and their thermophysical properties studied. They belong to different PCM groups: inorganic, sugar alcohol, and polymer.

The preselected materials were five inorganic compounds: $98 \%$ purity $\mathrm{KNO}_{3}$ from VWR prolabo (Llinars del Vallès, Spain), $98 \%$ purity $\mathrm{NaNO}_{2}$ from Sigma Aldrich (Saint Louis, MO, USA), and Panreac (Castellar del Vallès, Spain) provided with $98 \%$ purity $\mathrm{NaOH},>99 \%$ purity $\mathrm{NaNO}_{3}$ and $99 \%$ purity LiOH. Two organic compounds were preselected, more specifically two sugar alcohols: $99 \%$ purity Pentaerythritol from Sigma Aldrich and $>98 \%$ purity Pentaerythritol from Xi'an lyphar biotech Co. 
LTD (Xi'an, China), from the food industry under the US NF12/FCCV standard. Finally, a polymer was also preselected PBT from BASF (Ludwigshafen, Germany).

Eutectic mixtures were prepared by mixing both solid components in the eutectic proportion and melting the mixture at a temperature above their respective melting temperatures. Following this methodology, several eutectic compounds were not able to be prepared. Therefore, both components were dissolved in water, afterwards water was evaporated while the eutectic mixture remained. Table 4 shows the PCM melting temperature and enthalpy of the considered materials.

Table 4. Literature thermophysical characterization of PCMs.

\begin{tabular}{cccc}
\hline PCM & Melting Temperature $\left({ }^{\circ} \mathrm{C}\right)$ & Melting Enthalpy (J/g) & Reference \\
\hline $40 \mathrm{wt} \% \mathrm{KNO}_{3} / 60 \mathrm{wt} \% \mathrm{NaNO}_{3}$ & 222 & 100 & {$[10,11]$} \\
$61 \mathrm{wt} \% \mathrm{NaOH} / 39 \mathrm{wt} \% \mathrm{NaNO}_{2}$ & $232-265$ & $250-300$ & {$[14]$} \\
$87 \mathrm{wt} \% \mathrm{NaNO}_{2} / 13 \mathrm{wt} \% \mathrm{NaOH}$ & $230-232$ & $206-252$ & {$[14]$} \\
$80 \mathrm{wt} \% \mathrm{NaOH} / 20 \mathrm{wt} \% \mathrm{LiOH}$ & 215 & 280 & {$[8]$} \\
$70 \mathrm{wt} \% \mathrm{NaOH} / 30 \mathrm{wt} \% \mathrm{LiOH}$ & 215 & 280 & {$[9]$} \\
$\mathrm{NaNO}$ & 270 & 200 & {$[17]$} \\
Myo-inositol & 220 & 190 & {$[25]$} \\
$\mathrm{PBT}$ & $220-267$ & n.a. & {$[20]$} \\
\hline
\end{tabular}

\subsection{Health Hazard}

Health hazard is studied to detect potential operational and personal risks of the selected PCM. In this application, personal risks are not a critical parameter since the phase change material will be stored in an enclosed tank. Nevertheless, health hazard has to be taken into account considering that it indicates the standard procedures that need to be followed during the handling and operation of the selected PCM and the degree of personal protective equipment.

In this study, health hazard was evaluated by means of the National Fire Protection Association (NFPA) 704 diamond standard (Figure 1). The "NFPA 704: Standard system for the identification of the hazards of materials for emergency response" is a standard which has been developed by the National Fire Protection Association (NFPA). This standard visually provides the riskiness of common chemical products by means of a colored diamond. This diamond is divided in four indicators: flammability, health hazard, chemical reactivity, and special hazards. In this study, the blue indicator that corresponds to health hazard is followed, which is graded from 0 to 4 , being 0 non-hazardous substances and 4 the ones that could cause death or major residual injury by very short exposure.

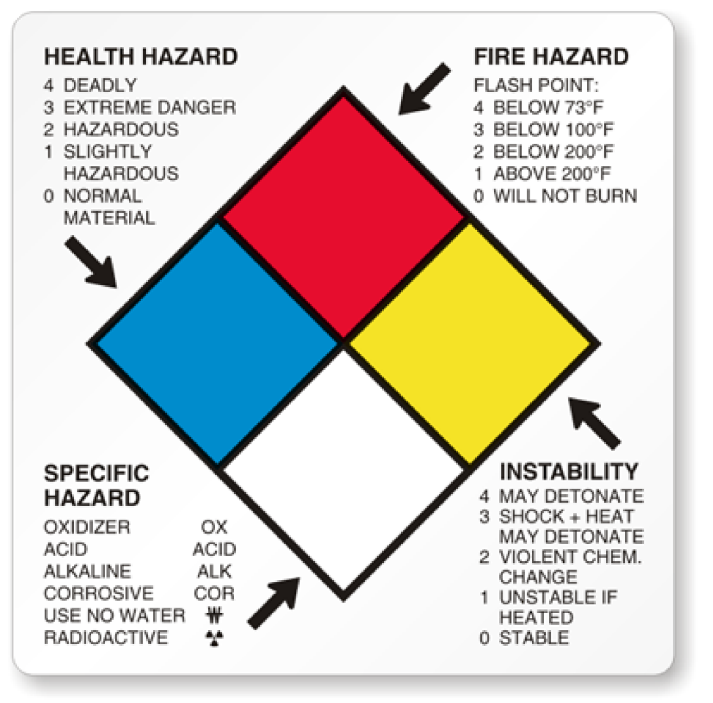

Figure 1. National Fire Protection Association (NFPA) 704 diamond standard [29]. 
Furthermore, the materials were also evaluated and labelled according to the Globally Harmonised System (GHS) of classification, labelling, and packaging of substances or mixtures (CLP). GHS classification is provided by 1392 companies from 20 notifications to the European Chemical Agents (ECHA).

According to 1272/2008/EC, a substance or mixture classified as hazardous and contained in packaging shall have a label including different information such as the name and contact of the supplier, the nominal quantity of the substance, and product identifiers, if applicable, such as hazard pictograms, signal words, hazard statements, appropriate precautionary statements, etc. [30]. Therefore, the hazard statements of the studied materials were also analysed. The hazard statements are classified in three sub-groups: physical, health and environmental hazards. All statements are identified with an uppercase $\mathrm{H}$ followed by a number comprised in the range of two, three or four hundred for each sub-group respectively.

\subsection{Thermophysical Characterization}

The equipment used for themophysical characterization was a DSC 822e (Mettler Toledo, Columbus, OH, USA). The amount of sample used was around $10 \mathrm{mg}$ and experiments were performed under a $\mathrm{N}_{2}$ flow. Sugar alcohol and polymer samples were located into $40 \mu \mathrm{L}$ cold-welded aluminum crucibles. In order to avoid undesired chemical reactions with inorganic salt, these samples were analyzed using a reusable $30 \mu \mathrm{L}$ gold plated crucibles in the first stage selection, and then the selected materials, after assuring that their nature would not react with the crucibles, were located in cold-welded aluminum crucibles. The methodology followed to obtain the phase change temperature and enthalpy of the PCM is based on dynamic temperature programs from $50^{\circ} \mathrm{C}$ under their theoretical phase change temperatures to $50{ }^{\circ} \mathrm{C}$ above it. The equipment precision is $\pm 0.1{ }^{\circ} \mathrm{C}$ for temperature and $\pm 3 \mathrm{~J} / \mathrm{g}$ for enthalpy results.

\subsection{Thermal Stability}

Thermogravimetric analyses (TGA) were carried out in order to characterize PCM thermal decomposition. The equipment used was a TA Instrument Simultaneous SDTQ600 (New Castle, DE, USA), which allows DSC-TGA measurements up to $1500{ }^{\circ} \mathrm{C}$ and has a balance sensitivity of $0.1 \mu \mathrm{g}$. The analyses were performed under a $50 \mathrm{~mL} / \mathrm{min}$ air atmosphere to simulate real boundary conditions. The heating rate used to perform the thermogravimetric analysis was $10^{\circ} \mathrm{C} / \mathrm{min}$ from 40 to $600{ }^{\circ} \mathrm{C}$. Opened $100 \mu \mathrm{L}$ alumina crucibles used were filled with around $1 / 3$ volume of material leading to average sample masses of around $22 \mathrm{mg}$. This technique provides maxim working temperature and final degradation temperature of the analyzed materials.

\subsection{Cycling Stability}

Thermal cycling stability tests were performed to study changes in the thermophysical properties of the PCM after a certain number of solidification-melting cycles within the operating temperature range of the process in which the TES material will be implemented. The candidate materials were exposed to 10 and 50 complete solidification-melting cycles. The thermal cycles were performed in a muffle-type furnace N31H (NABERTHERM, Lilienthal, Germany) between $200{ }^{\circ} \mathrm{C}$ and $250{ }^{\circ} \mathrm{C}$, simulating real operating conditions. Samples of $10 \mathrm{~g} \pm 1 \mathrm{~g}$ of each material were enclosed in crucibles in air atmosphere. Porcelain crucibles were used for both materials. Furthermore, closed PTFE crucibles were also used in the case of myo-inositol in order to simulate closed systems that may affect material. Afterwards, phase change temperature and enthalpy were evaluated using DSC technique under the same conditions described in Section 3.3.

The chemical characterization was carried out using a Fourier transform infrared (FT-IR) spectroscopy with attenuated total reflectance (ATR), which analyses the PCM chemical degradation caused by thermal cycling. The advantage of ATR is the possibility of obtaining the spectra directly from the sample, without any specific sample preparation. The partial or total disappearance of 
the characteristic peaks and/or the appearance of new peaks can indicate that the material is being oxidized or degraded. This analysis was carried out with a PIKE MIRacle ${ }^{\mathrm{TM}}$ ATR sampling accessory with a Diamond/ZnSe ATR base, FT-IR 6300 (Hachioji, Tokyo, Japan). It allows analysing substances in solid and liquid states. It was optimized by a wavelength range between 4000 and $650 \mathrm{~cm}^{-1}$, and its standard spectral resolution is $4 \mathrm{~cm}^{-1}$ accounting for 64 infrared scans for each analysis; the data recorded are their means. Its functionality is based on the characteristic wave numbers at which the molecules vibrate in infrared frequencies.

\section{Results and Discussion}

\subsection{Health Hazard}

Table 5 shows the health hazard characterization of the considered inorganic candidates, in fact of the chemicals used to formulate the compounds produced. Following the NFPA 704 standard, potassium and sodium nitrates are hazardous. Moreover, sodium nitrite, sodium and lithium hydroxides can cause serious or permanent injury. Despite $\mathrm{KNO}_{3}$ and $\mathrm{NaNO}_{3}$ have the same HFPA value (2), GHS method labels sodium nitrate as more dangerous to the human beings since it causes damage to organs through prolonged or repeated exposure.

Table 5. Health hazard values according to NFPA 704 and Globally Harmonised System (GHS) of the considered inorganic materials [24,31].

\begin{tabular}{|c|c|c|c|}
\hline Material & NFPA 704 & & GHS \\
\hline \multirow{4}{*}{$\mathrm{KNO}_{3}$} & & $\mathrm{H} 272$ & May intensify fire; oxidizer \\
\hline & & Н315 & Causes skin irritation \\
\hline & & H319 & Causes serious eye irritation \\
\hline & & H335 & May cause respiratory irritation \\
\hline \multirow{5}{*}{$\mathrm{NaNO}_{3}$} & & $\mathrm{H} 272$ & \multirow{5}{*}{$\begin{array}{l}\text { May intensify fire; oxidizer } \\
\text { Causes eye irritation } \\
\text { Suspected of causing genetic defects } \\
\text { Causes damage to organs } \\
\text { Causes damage to organs through prolonged or } \\
\text { repeated exposure }\end{array}$} \\
\hline & & H320 & \\
\hline & & H341 & \\
\hline & & $\mathrm{H} 370$ & \\
\hline & & H372 & \\
\hline \multirow{5}{*}{$\mathrm{LiOH}$} & & $\mathrm{H} 290$ & May be corrosive to metals \\
\hline & & Н302 & Harmful if swallowed \\
\hline & & H314 & Causes severe skin burns and eye damage \\
\hline & & H318 & Causes serious eye damage \\
\hline & & $\mathrm{H} 412$ & Harmful to aquatic life with long lasting effects \\
\hline \multirow{10}{*}{$\mathrm{NaNO}_{2}$} & & $\mathrm{H} 272$ & \multirow{10}{*}{$\begin{array}{l}\text { May intensify fire; oxidizer } \\
\text { Toxic if swallowed } \\
\text { Causes serious eye irritation } \\
\text { Suspected of causing genetic defects } \\
\text { Suspected of damaging fertility or the unborn child } \\
\text { May cause harm to breast-fed children } \\
\text { Causes damage to organs } \\
\text { Causes damage to organs through prolonged or } \\
\text { repeated expose } \\
\text { Very toxic to aquatic life } \\
\text { Very toxic to aquatic life with long lasting effects }\end{array}$} \\
\hline & & Н301 & \\
\hline & & H319 & \\
\hline & & H341 & \\
\hline & & H361 & \\
\hline & & H362 & \\
\hline & & H370 & \\
\hline & & H373 & \\
\hline & & $\mathrm{H} 400$ & \\
\hline & & $\mathrm{H} 410$ & \\
\hline \multirow{5}{*}{$\mathrm{NaOH}$} & & $\mathrm{H} 290$ & May be corrosive to metals \\
\hline & & H314 & Causes severe skin burns and eye damage \\
\hline & & H315 & Causes skin irritation \\
\hline & & H318 & Causes serious eye damage \\
\hline & & H319 & Causes serious eye irritation \\
\hline
\end{tabular}


Table 6 shows the health hazard evaluation of the considered materials following both the NFPA 704 diamond standard method and the GHS methods. Organic materials studied have low health hazard ratio according to the NFPA 704, considering them as slightly hazardous; while the GHS standard shows that those materials cause irritation on living beings.

Table 6. Health hazard values according to NFPA 704 and GHS of the considered organic materials [31,32].

\begin{tabular}{lll}
\hline Material & GHS \\
\hline $\begin{array}{c}\text { Causes serious eye irritation } \\
\text { Polybutylene } \\
\text { terephthalate PBT } \\
\left(\mathrm{C}_{12} \mathrm{H}_{12} \mathrm{O}_{4}\right)_{\mathrm{n}}\end{array}$ & $\begin{array}{l}\text { Causes skin irritation } \\
\text { Causes serious eye irritation }\end{array}$ & $\begin{array}{l}\text { May cause respiratory irritation } \\
\text { M3335 }\end{array}$ \\
\hline
\end{tabular}

If $\mathrm{LiOH}, \mathrm{NaNO}_{2}$, or $\mathrm{NaOH}$ were selected as ideal candidates, a specific safety study would be required. This study could lead to some system design modifications, so their economic impacts should also be considered.

\subsection{Thermophysical Characterization}

To confirm the literature phase change temperature and enthalpy of fusion of the studied materials, DSC analyses were carried out for each material listed in Table 4. Table 7 shows the comparison between the experimental melting enthalpy and temperature of the considered inorganic materials, obtained following the protocols described in Section 3.3, and the values reported by the literature.

Several inorganic salts mixtures have complex phase diagrams such as $\mathrm{NaNO}_{2} / \mathrm{NaOH}$ mixtures. It is difficult to ensure homogeneous eutectic composition along the whole material, especially for large quantities ( $>1000 \mathrm{~kg}$ ) [33]. Along the DSC experimental tests, it was noticed that $70 \mathrm{wt} \% \mathrm{NaOH} / 30$ wt $\% \mathrm{LiOH}$ did not show phase change, and this is probably because the mixture resulted is not homogeneous (not a proper eutectic mixture). However, despite of the adopted composition $80 \mathrm{wt} \%$ $\mathrm{NaOH} / 20 \mathrm{wt} \% \mathrm{LiOH}$ experimental phase change temperature is in concordance with the values found in literature, phase change enthalpy is much lower than expected. The eutectic phase solidification is a kinetic process that is governed by multiple hardly controllable factors, for that reason the DSC tests showed differences with the enthalpy values reported in the literature. Similar difficulties as the ones encountered for the latter material were faced while the characterization of $87 \mathrm{wt} \% \mathrm{NaNO}_{2} / 13 \mathrm{wt} \%$ $\mathrm{NaOH}$ and 39 wt $\% \mathrm{NaNO}_{2} / 61 \mathrm{wt} \% \mathrm{NaOH}$ was carried out.

Unlike the previous materials, $\mathrm{NaNO}_{2}$ and $40 \mathrm{wt} \% \mathrm{KNO}_{3} / 60 \mathrm{wt} \% \mathrm{NaNO}_{3} \mathrm{DSC}$ results showed almost the same values as the literature, suitable latent heat storage capacity, and sharp phase change temperature. However, sodium nitrite $\left(\mathrm{NaNO}_{2}\right)$ experimental phase change temperature exceeds the maximum acceptable temperature fixed by the output temperature of the solar field. All in all, the so-called "solar salt" is the only feasible inorganic material which meets the required thermophysical properties. 
Table 7. Differential scanning calorimeter (DSC) results of inorganic salts and eutectic mixtures $[8-12,14,17]$.

\begin{tabular}{|c|c|c|c|c|c|}
\hline \multirow{2}{*}{ Inorganic Materials } & \multicolumn{2}{|c|}{ Melting Temperature $\left({ }^{\circ} \mathrm{C}\right)$} & \multicolumn{2}{|c|}{ Melting Enthalpy (J/g) } & \multirow{2}{*}{ Observations } \\
\hline & Literature & Experimental & Literature & Experimental & \\
\hline $40 \mathrm{wt} \% \mathrm{KNO}_{3} / 60 \mathrm{wt} \% \mathrm{NaNO}_{3}$ & 222 & 221 & 100 & 94 & $\sqrt{ }$ No subcooling \\
\hline 87 wt $\% \mathrm{NaNO}_{2} / 13$ wt $\% \mathrm{NaOH}$ & $230-232$ & 232 & $206-252$ & 35 & $\begin{array}{l}\times \text { Poor eutectic phase } \\
\text { formation }\end{array}$ \\
\hline $70 \mathrm{wt} \% \mathrm{NaOH} / 30 \mathrm{wt} \% \mathrm{LiOH}$ & 215 & - & 280 & - & $\begin{array}{l}\times \text { No eutectic phase } \\
\text { formation }\end{array}$ \\
\hline $\mathrm{NaNO}_{2}$ & 270 & 281 & 200 & 178 & $\begin{array}{c}\times \text { Phase change } \\
\text { temperature out of range } \\
\sqrt{ } \text { High latent heat storage } \\
\text { capacity }\end{array}$ \\
\hline
\end{tabular}

Table 8 shows the experimental melting temperature and enthalpy of the considered organic materials obtained from DSC tests. Pentaerythitol solid-liquid phase change enthalpy was lower than equipment resolution, so it could not be measured accurately. On the other hand, DSC tests confirm the phase change temperature reported in the literature for myo-inositol $\left(\mathrm{C}_{6} \mathrm{H}_{12} \mathrm{O}_{6}\right)$ [25] as well as for polybutylene terephthalate (PBT) $\left(\left(\mathrm{C}_{12} \mathrm{H}_{12} \mathrm{O}_{4}\right)_{n}\right)$ [20]. The measured melting enthalpy of myo-inositol was $223 \mathrm{~J} / \mathrm{g}$, higher than the one reported in previous studies [25]. However, measured PBT melting enthalpy was very low $(49 \mathrm{~J} / \mathrm{g})$ and was not reported in the literature to have a comparison.

Table 8. DSC results of organic materials (polymer and sugar alcohol) [20,24,25].

\begin{tabular}{|c|c|c|c|c|c|}
\hline \multirow{2}{*}{$\begin{array}{l}\text { Organic } \\
\text { Material }\end{array}$} & \multicolumn{2}{|c|}{ Melting Temperature $\left({ }^{\circ} \mathrm{C}\right)$} & \multicolumn{2}{|c|}{ Melting Enthalpy (J/g) } & \multirow{2}{*}{ Comments } \\
\hline & Literature & Experimental & Literature & Experimental & \\
\hline Pentaerythritol & $258-260$ & - & - & - & $\begin{array}{l}\times \text { Did not show solid-liquid phase } \\
\text { change peak }\end{array}$ \\
\hline Myo-Inositol & 220 & 235 & 190 & 223 & $\begin{array}{l}\times \text { High difference between solidification } \\
\text { and melting temperature }\left(>35^{\circ} \mathrm{C}\right) \\
\sqrt{ } \text { High latent heat storage capacity } \\
\sqrt{ } \text { Phase change temperature within } \\
\text { the range }\end{array}$ \\
\hline $\begin{array}{l}\text { Polybutylene } \\
\text { terephthalate } \\
\text { (PBT) }\end{array}$ & $220-267$ & 227 & - & 49 & $\begin{array}{l}\times \text { High difference between solidification } \\
\text { and melting temperature }\left(>25^{\circ} \mathrm{C}\right) \\
\times \text { Low latent heat storage capacity } \\
\sqrt{ } \text { Phase change temperature within } \\
\text { the range }\end{array}$ \\
\hline
\end{tabular}

Therefore, given the thermophysical results obtained in the laboratory, three materials, $40 \mathrm{wt} \%$ $\mathrm{KNO}_{3} / 60 \mathrm{wt} \% \mathrm{NaNO}_{3}$, myo-inositol, and PBT, were preselected and deeper characterized in the following section.

\subsection{Thermal Stability}

Thermal gravimetric analyses were performed on the two inorganic salts $\left(40\right.$ wt $\% \mathrm{KNO}_{3}$ / $60 \mathrm{wt} \% \mathrm{NaNO}_{3}$ and $\mathrm{NaNO}_{2}$ ) and two organic materials (PBT and myo-inositol) shown in Figure 2. Fernández et al. [34] defined as maximum working temperature, the one for which the studied material lost $3 \%$ of its initial mass, considered the thermal decomposition starting point. Solar salt TGA results (Figure 2a) show that it starts losing mass at $500{ }^{\circ} \mathrm{C}$. However, as this loss was below $3 \%$ no thermal decomposition is considered, making it suitable for the desired final application. 


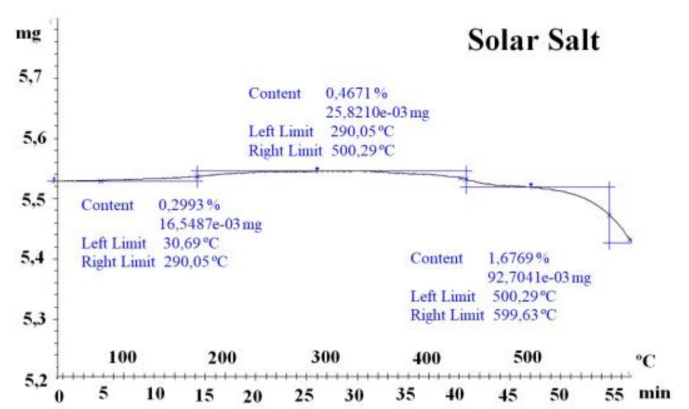

(a)

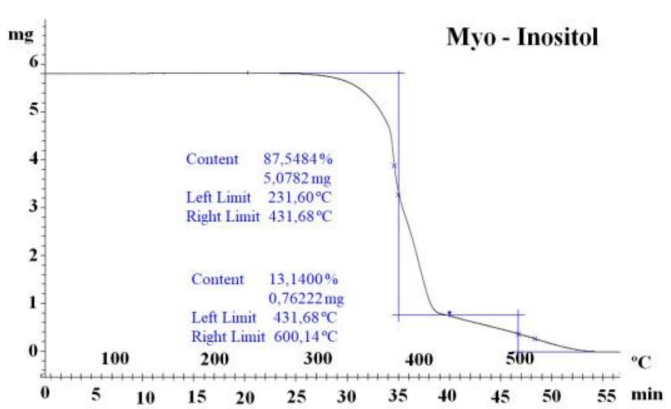

(b)

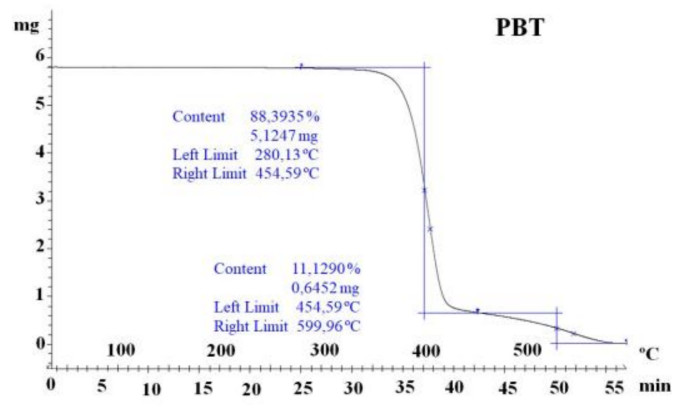

(c)

Figure 2. Thermal gravimetric analysis of (a) solar salt (40 wt \% $\mathrm{KNO}_{3} / 60$ wt $\% \mathrm{NaNO}_{3}$ ), (b) myo-inositol, and (c) polybutylene terephthalate (PBT).

On the other hand, the organic materials suffered a severe decomposition. Figure $2 b$ shows how myo-inositol loses $88 \%$ of its initial mass between $230{ }^{\circ} \mathrm{C}$ and $430^{\circ} \mathrm{C}$. The thermal decomposition keeps on until $600^{\circ} \mathrm{C}$ at a lower rate. The same behavior can be observed for PBT in Figure 2c. PBT mass loss goes from $288^{\circ} \mathrm{C}$ to $454^{\circ} \mathrm{C}$. The mass of PBT keeps dropping down at a lower rate between $454{ }^{\circ} \mathrm{C}$ and $600^{\circ} \mathrm{C}$. Both organic materials experienced rather a combustion reaction or a severe decomposition at high temperatures, which make them unsuitable candidates. Nonetheless, due to its high phase change enthalpy and low cost, in the next section myo-inositol is put through the cycling stability in a close crucible.

\subsection{Cycling Stability}

Table 9 shows the thermophysical properties of the two pre-selected candidates, $40 \mathrm{wt} \% \mathrm{KNO}_{3} /$ $60 \mathrm{wt} \% \mathrm{NaNO}_{3}$ and myo-inositol, after being cycled 10 and 50 times. The solar salt neither shows any kind of temperature hysteresis nor subcooling. Additionally, its phase change enthalpy hardly varies after the cycling process, and that variation does not affect its storing capacity.

Table 9. Cycling stability tests results.

\begin{tabular}{ccccccc}
\hline Material & $\begin{array}{c}\text { Cycling } \\
\text { System Type }\end{array}$ & Cycles & $\begin{array}{c}\text { Melting } \\
\text { Enthalpy (J/g) }\end{array}$ & $\begin{array}{c}\text { Solidification } \\
\text { Enthalpy (J/g) }\end{array}$ & $\begin{array}{c}\text { Melting } \\
\text { Temperature }\left({ }^{\circ} \mathbf{C}\right)\end{array}$ & $\begin{array}{c}\text { Solidification } \\
\text { Temperature }\left({ }^{\circ} \mathbf{C}\right)\end{array}$ \\
\hline $40 \mathrm{wt} \%$ & \multirow{2}{*}{ Tpen } & 10 & 94.84 & 92.72 & 220.75 & 219.70 \\
$\mathrm{KNO}_{3} / 60 \mathrm{wt} \%$ & & 90 & 94.07 & 91.02 & 222.07 & 221.21 \\
$\mathrm{NaNO}_{3}$ & & 0 & 249.76 & 80.31 & 222.18 & 221.37 \\
\hline \multirow{3}{*}{ Myo-Inositol } & \multirow{2}{*}{ Closed, in air } & 10 & 109.15 & 65.65 & 223.26 & 189.91 \\
& atmosphere & 50 & 40.66 & n.a. & 215.31 & 166.61 \\
& & & & & n.a. \\
\hline
\end{tabular}

n.a.-not available. 
On the other hand, myo-inositol did not stand the thermal cycles as well as the solar salt. Despite the fact that its phase change temperature does not vary, its phase change enthalpy decreases along the cycling process. After 10 cycles, myo-inositol lost more than half of its storing capacity $(66 \%)$ but was still over the discarding threshold. However, when characterizing the 50 cycles myo-inositol sample, the results showed a melting enthalpy $83.6 \%$ lower than the initial one. Because of the final application working conditions, the selected material should endure daily phase change cycles; therefore, myo-inositol does not meet the requirements.

An infrared spectrometry is carried out to check the stability of the material samples after thermal cycling. Figure 3 shows the solar salt and myo-inositol spectrums, respectively after 0, 10, and 50 cycles. The solar salt infrared spectrum (Figure 3a) reveals the same chemical structure presence on the three different samples. Therefore, in combination with the results obtained for its thermophysical characterization, it can be concluded that solar salt bears cycling processes successfully.

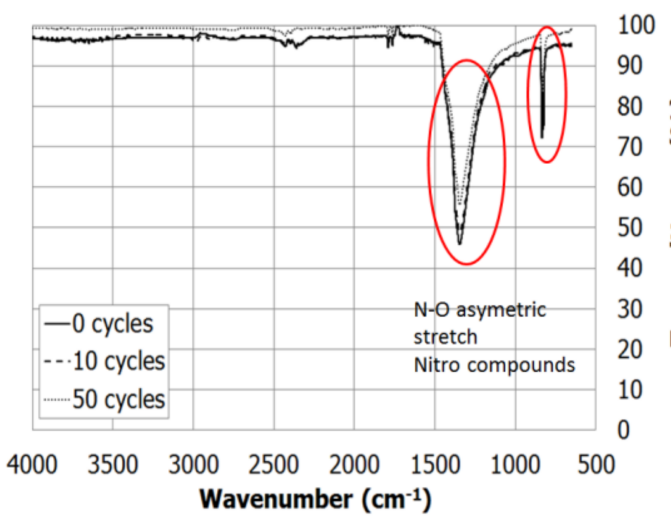

(a)

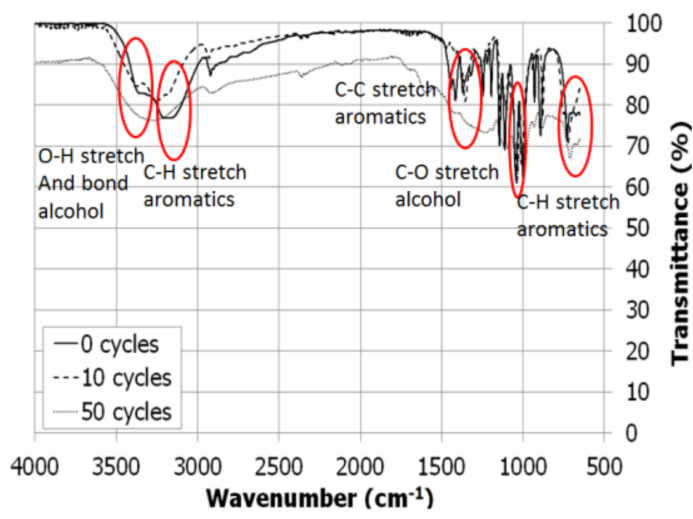

(b)

Figure 3. Infrared attenuated total reflectance (IR-ATR) spectrums after 0, 10, and 50 thermal cycles of (a) solar salt; and (b) myo-inositol.

On the other side, Figure $3 \mathrm{~b}$ reveals the alterations in myo-inositol chemical structure when being cycled. In spite of the closed crucible for this experiment, the remaining oxygen still oxidizes myo-inositol and other degradation reactions might take place. Hence, myo-inositol would need an inert atmosphere, which would increase the required cost for the design and maintenance of a real application plant. For that reason, myo-inositol must be discarded.

\section{Conclusions}

A deep material screening was performed in the literature finding a total of 26 interesting PCMs in the temperature range of $210-270{ }^{\circ} \mathrm{C}$. From that first selection, nine materials were analyzed according to their health hazard and preselected to be thermophysically characterized; measuring their phase change enthalpy and temperature and studying their thermal behavior. This selection was based on their enthalpy found in the literature and their price. From the DSC results, three candidates were pre-selected to be deeply studied, the eutectic called "solar salt," $40 \mathrm{wt} \% \mathrm{KNO}_{3} / 60 \mathrm{wt} \% \mathrm{NaNO}_{3}$, myo-inositol, and PBT.

Those three materials were tested through thermal stability by means of TGA. Myo-inositol and PBT suffered severe thermal decomposition from $230-288^{\circ} \mathrm{C}$ respectively. Due to myo-inositol thermal characterization and cheap price, it was thermally cycled in a closed system, but it was not stable after 50 cycles. All in all, from 26 candidates, including inorganic salts and organic materials that can be used as PCMs in applications with a working temperature range from 210 to $270{ }^{\circ} \mathrm{C}$, even though its limited enthalpy of fusion, solar salt succeeded on every performed test. 
Acknowledgments: This work was partially funded by the European Union's Horizon 2020 Research \& Innovation Programme under Grant Agreement 723596 with reference name Innova MicroSolar. This work was partially funded by the Ministerio de Economía y Competitividad de España (ENE2015-64117-C5-1-R (MINECO/FEDER) and ENE2015-64117-C5-3-R (MINECO/FEDER)). The authors would like to thank the Catalan Government for the quality accreditation given to their research group (2017 SGR 1537). GREA is certified agent TECNIO in the category of technology developers from the Government of Catalonia. José Miguel Maldonado would like to thank the Spanish Government for his research fellowship (BES-2016-076554). Aran Solé would like to thank Ministerio de Economía y Competitividad de España for Grant Juan de la Cierva, FJCI-2015-25741. Alvaro de Gracia has received funding from the European Union's Horizon 2020 research and innovation programme under the Marie Sklodowska-Curie grant agreement No. 712949. Angel G. Fernández would like to acknowledge the financial support provided by GIZ "Programa de pasantía en el extranjero en tecnologías de concentración solar para investigadores" and CONICYT/FONDAP 15110019 "Solar Energy Research Center" SERC-Chile.

Author Contributions: Luisa F. Cabeza and Alvaro de Gracia conceived and designed the experiments; Marc Martín and Margalida Fullana-Puig performed the experiments; Ángel G. Fernández, José Miguel Maldonado and Aran Solé analyzed the data; José Miguel Maldonado, Margalida Fullana-Puig and Marc Martín wrote the paper. All authors contributed to discuss the obtained results. The article was reviewed by every single co-author.

Conflicts of Interest: The authors declare no conflict of interest.

\section{References}

1. ISE, Fraunhoffer. Levelized Cost of Electricity Renewable Energy Technologies. Available online: https:/ / www.ise.fraunhofer.de/en/publications/veroeffentlichungen-pdf-dateien-en/studien-undkonzeptpapiere/study-levelized-cost-of-electricity-renewable-energies.pdf (accessed on 19 February 2018).

2. Zalba, B.; Marín José, M.A.; Cabeza, L.F.; Mehling, H. Review on thermal energy storage with phase change: Materials, heat transfer analysis and applications. Appl. Therm. Eng. 2003, 23, 251-283. [CrossRef]

3. Haillot, D.; Bauer, T.; Kröner, U.; Tamme, R. Thermal analysis of phase change materials in the temperature range $120-150{ }^{\circ} \mathrm{C}$. Thermochim. Acta 2011, 513, 49-59. [CrossRef]

4. Del Barrio, E.P.; Godin, A.; Duquesne, M.; Daranlot, J.; Jolly, J.; Alshaer, W.; Kouadio, T.; Sommier, A. Characterization of different sugar alcohols as phase change materials for thermal energy storage applications. Sol. Energy Mater. Sol. Cells 2017, 159, 560-569. [CrossRef]

5. Bayón, R.; Coco, S.; Barcenilla, M.; Espinet, P.; Imbuluzqueta, G. Feasibility of Storing Latent Heat with Liquid Crystals. Proof of Concept at Lab Scale. Appl. Sci. 2016, 6, 121. [CrossRef]

6. Miró, L.; Barreneche, C.; Ferrer, G.; Solé, A.; Martorell, I.; Cabeza, L.F. Health hazard, cycling and thermal stability as key parameters when selecting a suitable phase change material (PCM). Thermochim. Acta 2016, 627-629, 39-47. [CrossRef]

7. Gasia, J.; Martín, M.; Solé, A.; Barreneche, C.; Cabeza, L.F. Phase Change Material Selection for Thermal Processes Working under Partial Load Operating Conditions in the Temperature Range between 120 and $200{ }^{\circ}$ C. Appl. Sci. 2017, 7, 722. [CrossRef]

8. Kenisarin, M. High-temperature phase change materials for thermal energy storage. Renew. Sustain. Energy Rev. 2010, 14, 955-970. [CrossRef]

9. Waschull, J.; Müller, R.; Römer, S. Investigation of Phase Change Materials for Elevated Temperatures. In Proceedings of the 11th International Conference on Thermal Energy Storage EFFSTOCK, Stockholm, Sweden, 14-17 June 2009; pp. 14-17.

10. Kamimoto, M.; Tanaka, T.; Tani, T.; Horigome, T. Investigation of nitrate salts for solar latent heat storage. Sol. Energy 1980, 24, 581-587. [CrossRef]

11. Fernandez, A.G.; Lasanta, M.I.; Perez, F.J. Molten Salt Corrosion of Stainless Steels and Low-Cr Steel in CSP Plants. Oxid. Met. 2012, 78, 329-348. [CrossRef]

12. Greis, K.; Bahamdan, M.; Uwais, B.M. The phase diagram of the system NaNO-KNO, by differential scanning calorimetry. Thermochim. Acta 1985, 86, 343-350. [CrossRef]

13. Berg, R.W.; Kerridge, D.H.; Larsen, P.H. $\mathrm{NaNO}_{2}+\mathrm{NaNO}_{3}$ Phase Diagram: New Data from DSC and Raman Spectroscopy. J. Chem. Eng. Data 2006, 51, 34-39. [CrossRef]

14. Takahashi, Y.; Kamimoto, M.; Abe, Y.; Sakamoto, R.; Kanari, K.; Ozawa, T. Investigation of latent heat thermal energy storage materials: $\mathrm{V}$. thermoanalytical evaluation of binary eutectic mixtures and compounds of $\mathrm{NaOH}$ with $\mathrm{NaNO}_{3}$ or $\mathrm{NaNO}_{2}$. Thermochim. Acta 1988, 123, 233-245. [CrossRef] 
15. Heine, D.; Heess, F.; Groll, M. Investigation of the corrosion and melting/freezing behavior of high temperature latent storage materials. In Proceedings of the 14th Intersociety Energy Conversion Engineering Conference, Boston, MA, USA, 5-10 August 1979; pp. 459-466.

16. Laing, D. Energy Storage for Concentrating Solar Power Plants; Energy Forum: Hannover, Germany, 2008; pp. 1-25.

17. Tye, R.P.; Bourne, J.G.; Desjarlais, A.O. Thermal Energy Storage Material Thermophysical Property Measurement and Heat Transfer Impact; Dynatech R/D Co.: Cambridge, MA, USA, 1976.

18. Risueño, E.; Faik, A.; Rodríguez-aseguinolaza, J.; Blanco-rodríguez, P.; Gil, A. Mg-Zn-Al eutectic alloys as phase change material for latent heat thermal energy storage. Energy Procedia 2015, 69, 1006-1013. [CrossRef]

19. Kotzé, J.P.; von Backstrom, T.W.; Erens, P.J. High temperature thermal energy storage utilizing metallic phase change materials and metallic heat transfer fluids. J. Sol. Energy Eng. 2013, 135, 1-6. [CrossRef]

20. Ge, H.; Li, H.; Mei, S.; Liu, J. Low melting point liquid metal as a new class of phase change material: An emerging frontier in energy area. Renew. Sustain. Energy Rev. 2013, 21, 331-346. [CrossRef]

21. Fernández, A.I.; Barreneche, C.; Belusko, M.; Segarra, M.; Bruno, F.; Cabeza, L.F. Solar Energy Materials and Solar Cells Considerations for the use of metal alloys as phase change materials for high temperature applications. Sol. Energy Mater. Sol. Cells 2017, 171, 275-281. [CrossRef]

22. Software CES EduPack 2015 Version:15.3.10. Granta Design Limited: Cambridge, UK, 2015.

23. Stankus, S.V.; Khairulin, R.A. The peculiarities of crystallization of low-temperature eutectic in magnesium-lead system. Thermophys. Aeromech. 2010, 17, 205-211. [CrossRef]

24. PubChem. Available online: https://pubchem.ncbi.nlm.nih.gov (accessed on 20 March 2017).

25. Solé, A.; Neumann, H.; Niedermaier, S.; Martorell, I.; Schossig, P.; Cabeza, L.F. Stability of sugar alcohols as PCM for thermal energy storage. Sol. Energy Mater. Sol. Cells 2014, 126, 125-134. [CrossRef]

26. Hérault, D.; Rodembusch, F.; Campo, L.; Gingras, M.; Cerveau, G.; Corriu, R.J.P. Valorization of by-products of the sugar industry: New nanostructured hybrid materials containing sugar derived structures. C. R. Acad. Sci. Ser. IIC Chem. 2010, 13, 566-574. [CrossRef]

27. Hu, P.; Zhao, P.; Jin, Y.; Chen, Z. Experimental study on solid-solid phase change properties of pentaerythritol (PE)/nano-AIN composite for thermal storage. Sol. Energy 2014, 102, 91-97. [CrossRef]

28. Nkhonjera, L.; Kuboth, M.; König-haagen, A.; John, G.; Brüggemann, D.; Bello-ochende, T. Experimental investigation of a finned pentaerythritol-based heat storage unit for solar cooking at $150-200{ }^{\circ} \mathrm{C}$. Energy Procedia 2016, 93, 160-167. [CrossRef]

29. Largest Selection of Safety Labels Online. Available online: https://www.mysafetylabels.com (accessed on 16 February 2018).

30. MSDS-Europe-A Real Alternative to an MSDS Software'. Available online: http:/ / www.msds-europe.com/ (accessed on 13 December 2018).

31. Science Lab n.d. Available online: https://www.sciencelab.com/ (accessed on 20 November 2017).

32. BASF. Ultradur B 4520 Uncolored Polybutylene Terephthalate; BASF: Ludwigshafen, Germany, 2015.

33. Bauer, T.; Laing, D.; Tamme, R. Overview of PCMs for concentrated solar power in the temperature range 200 to $350{ }^{\circ}$ C. Adv. Sci. Technol. 2010, 74, 272-277. [CrossRef]

34. Fernández, A.G.; Veliz, S.; Fuentealba, E.; Galleguillos, H. Thermal characterization of solar salts from north of Chile and variations of their properties over time at high temperature. J. Therm. Anal. Calorim. 2017, 128, 1241-1249. [CrossRef]

(C) 2018 by the authors. Licensee MDPI, Basel, Switzerland. This article is an open access article distributed under the terms and conditions of the Creative Commons Attribution (CC BY) license (http:/ / creativecommons.org/licenses/by/4.0/). 